\title{
P295: Endoscopes' maintenance: results from an audit conducted in Beni-Messous University Hospital Algiers in 2012
}

\author{
G Brahimi*, R Belkaid, A Larinouna, C Lafer, A Soukehal \\ From 2nd International Conference on Prevention and Infection Control (ICPIC 2013) \\ Geneva, Switzerland. 25-28 June 2013
}

\section{Introduction}

Medical devices used in endoscopy should be disinfected according to best practices to eliminate microorganisms on their surfaces.

\section{Objectives}

Evaluate the practical disinfection of endoscopes.

\section{Methods}

The audit was conducted from 03 to 19 January 2012, in the services using endoscopy. Data collection was done through observation and interviews of staff responsible for the disinfection of endoscopes from a predetermined rubric. Entry and data analysis were performed on Epi-info6.

\section{Results}

7 services use Endoscopy (Otorhinolaryngology, Pulmonary and Allergy Medicine, Allergy, General surgery, Pulmonary function tests, CPPA, Internal Medicine, Pediatric). 15 people responsible for the disinfection of endoscopes were audited. $66.7 \%$ are nursinggraduates, $21.4 \%$ are instrumentalists. More than $50 \%$ have an average experience of $14 \pm 9$ years. Disinfection of endoscopes every morning before first use is achieved in $40 \%$ of cases. The seal is tested in $74 \%$ of cases.

The second cleaning is never done. The final rinsing takes place with tapwater, drying with a sterile field in $40 \%$ and by blowing compressed air in $20 \%$ of cases.

The storage isn't daily cleaned and disinfected. Periodic maintenance of the unit is done neither by the manufacturer nor the distributor.

Department of Epidemiology and Preventive Medicine, CHU Béni-Messous, Algiers, Algeria

\section{Conclusion}

This audit revealed the lack of necessary materials, and non-compliance with the disinfection protocol of endoscopes in some services and the absence of microbiological testing.

\section{Competing interests}

None declared.

Published: 20 June 2013

doi:10.1186/2047-2994-2-S1-P295

Cite this article as: Brahimi et al:: P295: Endoscopes' maintenance: results from an audit conducted in Beni-Messous University Hospital Algiers in 2012. Antimicrobial Resistance and Infection Control 2013 2(Suppl 1):P295.

Submit your next manuscript to BioMed Central and take full advantage of:

- Convenient online submission

- Thorough peer review

- No space constraints or color figure charges

- Immediate publication on acceptance

- Inclusion in PubMed, CAS, Scopus and Google Scholar

- Research which is freely available for redistribution

Submit your manuscript at www.biomedcentral.com/submit
() Biomed Central

\section{Algiers, Algeria}

